\title{
The UK Media and 'Europe': From Permissive Consensus to Destructive Dissent
}

\author{
Oliver Daddow ${ }^{1}$
}

'This may be the most important proposition revealed by history: "At the time, no one knew what was coming"', 2

With Britain's main parties of government deeply divided on the question of European integration, its politicians have been reticent to the point of paranoia about opening up national debates about the European Economic Community (EEC) and European Union (EU). The national media, by contrast, have had no such qualms about professing their opinions on the merits and downsides of the European project and Britain's contribution to it. This article argues that on the issue of 'Europe' most organs of the British media have, in a variety of ways and for various reasons, been on a journey from 1973 to the present, from permissive consensus to destructive dissent. In putting forward this interpretation the article adapts Liesbet Hooghe and Gary Marks's judgement that, since the signing of the Treaty of Maastricht in 1991, European policy-making elites have progressively more had to 'look over their shoulders when negotiating European issues'. This is because public interest in notionally European-level affairs has risen in proportion to the number and contentiousness of landmark decisions being taken at the supranational level. Crucially, there has been a marked rise in continent-wide Euroscepticism, with national politicians having to 'make room for a more Eurosceptical public' when coming to decisions on European integration,

\footnotetext{
${ }^{1}$ Thanks to Simona Guerra, Philip Lynch and Dominic Wring for reading and commenting on previous manifestations of this article. I gained useful feedback and sources from the participants at the Chatham House study groups; John Peet and Willie Paterson were particularly helpful in talking over the key issues from their uniquely insightful perspectives.

${ }^{2}$ Haruki Murakami, 1Q84, book 1, trans. Jay Rubin (London: Harvill Secker, 2011), p.11.
} 
especially on sensitive topics such as fiscal union and constitution-building. ${ }^{3}$ The title of this article reflects the specificity of the British case, where a seismic shift took place during the 1980s. Widespread (but by no means total) media support, sometimes manifest as quiet or just plain uninterested acquiescence in the European project conceived in its "common market' guise, has given way to a vigorously partisan hostility bordering on a nationalist and in some arenas xenophobic approach to the coverage of European affairs.

The 'destructive' element in this process locates the British case at the very hardest of 'hard' variants of Eurosceptical opinion. ${ }^{4}$ Chris Gifford has remarked that hard Euroscepticism is that strain of populist disillusionment with the European project which increased in appeal inside and outside parliament during the Maastricht Treaty ratification process 1991-93. It takes various forms depending on medium and is a manifestation of the nation's troublesome search for a cohesive British identity after the loss of Empire in which 'Europe' plays the part of 'an "other" against which the "new" Britain can be defined'. ${ }^{5}$ Peter Anderson and Anthony Weymouth argue that British identity has increasingly come to be constructed out of opposition on political, economic, military and ideological grounds to 'the presence of and perceived threat from an external "Other", namely continental Europe'. ${ }^{6}$ This narrative expresses suspicion and/or antagonism not so much towards the EU manifestation of European integration but to the ideal of integration itself. Hard Eurosceptic discourse in

\footnotetext{
${ }^{3}$ Liesbet Hooghe and Gary Marks, 'A Postfunctionalist Theory of European Integration: From Permissive Consensus to Constraining Dissensus', British Journal of Political Science, 39: 1 (2009), pp.1-23 (at p.5 and p.9).

${ }^{4}$ The 'hard/soft' model has been developed and refined within work on comparative Euroscepticism; see for example Paul Taggart and Aleks Szczerbiak, Opposing Europe? The Comparative Party Politics of Euroscepticism (Oxford: Oxford University Press, 2004).

${ }^{5}$ Chris Gifford, 'The Rise of Post-imperial Populism: The Case of Right-wing Euroscepticism in Britain', European Journal of Political Research, 45: 5 (2006), pp.851-869 ( p.856).

${ }^{6}$ Peter J. Anderson and Anthony Weymouth, Insulting the Public? The British Press and the European Union (London: Longman, 1999), p.5.
} 
Britain, notes Vivien Schmidt, exaggerates 'the negative aspects of the impact of EU policies and practices'. ${ }^{7}$

Hard Eurosceptic framing questions the legitimacy of any EU-level law or treaty change that might be imposed on the democratic and 'free' British by the tyranny of a devious centralizing project across the English Channel. It is something of a Realist zero-sum understanding of power relations that equates 'more Europe' with 'less Britain'. As this still shot from the opening credits to Channel 4's "Coach Trip" nicely illustrates, the cultural context within which this interpretation has come to form, sediment and be transmitted around British culture and society is important. Geographical separation has bred a sense of psychological distance that the British have rarely felt able or particularly willing to bridge effectively, and less and less so since the 1980s.

Image 1: Opening credit of "Coach Trip".

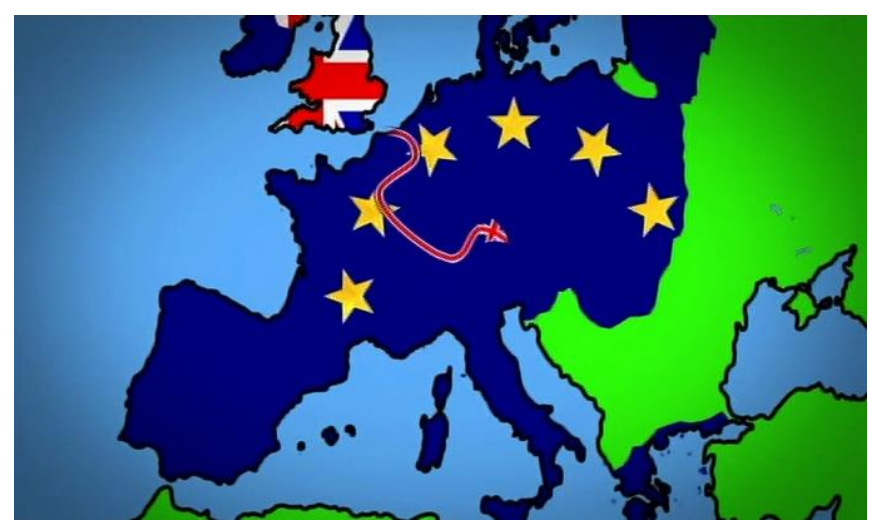

Copyright 12 Yard Productions
Commented [J1]: Does this need any copyright permission? Permission granted and relevant emailswith Heidi.

The coach tour of Europe undertaken by participants in this 'reality' television show is represented less as a relaxing holiday abroad than a dangerous military raid into enemy

${ }^{7}$ Vivien A. Schmidt, 'Adapting to Europe: Is it Harder for Britain?', British Journal of Politics and International Relations, 8: 1 (2006), pp.15-33 (p.30). 
territory using imagery not dissimilar from that used in the opening credits of the popular UK situation comedy "Dad's Army". ${ }^{8}$ Importantly, the coach departs from an England, Scotland and Wales wrapped in the British Union Jack flag and enters a 'continent' (and Republic of Ireland) bathed in the EU flag. The former countries, it implies, are not part of the EU, psychologically speaking, and as a result the British are always going 'to' Europe rather than being a comfortable, integral part of it already. That sense of 'belonging' is always in doubt.

This article explains the cultural diffusion of hard Euroscepticism in Britain with reference to what is termed the 'Murdoch effect' on the way European affairs have come to be reported in many press and to a degree broadcast outlets in the UK's 'liberal media system', ${ }^{9}$ where the search for competitive advantage has been a perennial ownership concern. As Menno Spiering argues, Euroscepticism has become big business as ideologically committed and commercially savvy newspaper proprietors and editors have sensationalized EU-related matters for public consumption. In particular, they have alighted on 'stories about foreigners trying to lord it over "us", or about absurd rulings imposed on the UK by alien institutions'. ${ }^{10}$ At best the European polity is notional and weakly formed and European affairs are reported by a sceptical media in a country where knowledge of the EU political system is the lowest of all member states. Even dramatic advances such as the European Constitution are 'barely known' to the public, ${ }^{11}$ so UK tabloid coverage tends to exaggerate for effect on the tacit understanding that there will be, at best, a minimal and uncoordinated riposte either from EU-friendly politicians or other media. Meanwhile, politicians from across the main parties have been complicit in denigrating the EU for party gain, with a dwindling number of openly pro-European politicians afraid to challenge a hard

\footnotetext{
${ }^{8}$ Explored in Oliver Daddow, New Labour and the European Union: Blair and Brown's Logic of History (Manchester: Manchester University Press, 2011), p.205.

${ }^{9}$ Arjen van Dalen, Erik Albæk and Claes de Vreese, 'Suspicious Minds: Explaining Political Cynicism among Political Journalists in Europe', European Journal of Communication, 26: 2 (2011), pp.147-162 (p.149).

${ }^{10}$ Menno Spiering, 'British Euroscepticism', European Studies, 20 (2004), pp.127-49 (p.139).

${ }^{11}$ Martin Gleissner and Claes H. De Vreese, 'News About the EU Constitution: Journalistic Challenges and Media Portrayal of the European Union Constitution', Journalism, 6: 2 (2005), pp.221-241 (p.223).
} 
Eurosceptical narrative revivified by the Eurozone crisis which has given rise to the unedifying notion that Britain is 'shackled to the corpse of Europe'. ${ }^{12}$ As we shall see, broadsheet newspapers express Euroscepticism in a more restrained fashion, while television broadcasters tend to achieve greater balance still. The general trend, however, has been towards the predominance of coverage tainted by hard Eurosceptical editorialization.

The article proceeds in three parts. The opening section sets the scene by assessing the nature of the UK media's change of heart on European integration since EEC accession in 1973. From general support for membership, manifest at the time of the 1975 membership referendum, a combination of dissatisfaction with the EU project and a questioning attitude towards UK membership itself have come to characterize the default media setting. The second section introduces work on the sociology of media ownership to explain this move from permissive consensus to destructive dissent as, in large measure, a function of developments in media and political coverage brought about by the expansion of the Murdoch empire through the 1980s. The final section considers the symbiosis that developed between Thatcherite Euroscepticism and the representations of 'Europe' in the popular press, suggesting that 'the Murdoch effect' is inextricably intertwined with 'the Thatcher effect' on contemporary Britain. The central argument through the piece is that a study of the former rather than latter provides the more persuasive explanation for the size and especially the manner of the collapse in media support for the EU in Britain since membership was achieved. Contestation arising from an ever-widening and deepening EU has created many opportunities for attacking all things European and the media, led by tabloid alarmism, have played a crucial enabling role in encouraging the Eurosceptic cause by legitimating political criticism of the EU. Not least, however, the media have worked synergistically with

${ }^{12}$ For instance Daniel Hannan, 'Britain is Shackled to the Corpse of Europe', Mail Online, 6 May 2012, http://www.dailymail.co.uk/debate/article-2140532/Francois-Hollande-French-president-Britain-shackledcorpse-Europe.html, accessed 25 June 2012. 
politicians to articulate a workable language of Euroscepticism that has taken hold of the popular imagination.

\section{From permissive consensus to destructive dissent}

Observers at the time of the 1975 UK referendum on continued membership of the EEC, as well as those looking back with the benefit of hindsight, are inclined to agree that: 'During the campaign, virtually all the mainstream national British press supported the Yes campaign, with the Communist Morning Star being the only notable national daily to back the No campaign'. ${ }^{13}$ Colin Seymour-Ure adds that Labour weeklies such as Tribune and the Transport and General Workers' Union monthly Record, with a regular circulation of 300,000 , provided valuable leadership to the No side in the press. ${ }^{14}$ More enduring still, Ernest Wistrich contends that the Daily Express was also in the No camp, in line with its Empire-first conception of Britain's world role and concomitant criticism of Britain's membership bids in the $1960 \mathrm{~s},{ }^{15}$ although it softened its opposition after the October 1971 parliamentary vote in favour of accession. ${ }^{16}$ Roy Greenslade points out that support for membership in UK countries other than England was less than fulsome with Scottish titles such as the trade union-run Scottish Daily News backing the No campaign. ${ }^{17}$ All in all, widespread press backing surely helped sway a British public which had been antipathetic to the EEC through the 1960s and early 1970s to the Yes side.

\footnotetext{
${ }^{13}$ Mark Baimbridge, 'The Pre-history of the Referendum', in Mark Baimbridge, ed., The 1975 Referendum on Europe, Volume 1: Reflections of the Participants (Exeter: Imprint Academic, 2007), pp.49-59 (p.59).

${ }^{14}$ Colin Seymour-Ure, 'Press', in David Butler and Uwe Kitzinger, The 1975 Referendum (London: Macmillan, 1976), pp214-245 (p.217).

${ }^{15}$ Ernest Wistrich, 'Lessons of the 1975 Referendum', in Baimbridge, ed., The 1975 Referendum, pp.109-120 (p112); Spiering, 'British Euroscepticism', p.132.

${ }_{16}$ Paul Gliddon, 'The British Foreign Office and Domestic Propaganda on the European Community, 1960 -72', Contemporary British History, 23: 2 (2009), pp.155-180 (pp.168-169).

${ }^{17}$ Roy Greenslade, Press Gang: How Newspapers make Profits from Propaganda (London: Macmillan, 2003), p. 275 .
} 
Partisan though some newspaper backing undoubtedly was, ${ }^{18}$ it surely also reflected the success of the pro-EEC movement in the government and civil service which actively sought to persuade the media, initially to support EEC membership bids and then to buttress the case for continued membership once inside the EEC. To begin with, the Yes campaign was better backed financially than the No campaign, as well as being better organized and more ruthlessly persistent in making its case to individual journalists and broadcasters. ${ }^{19}$ Moreover, by 1971 the Edward Heath government had mobilized supportive politicians and, as Paul Gliddon documents, top civil servants in the Foreign Office, who worked fervently behind the scenes to target key segments of the opinion-forming broadcast media in an information-come-propaganda campaign that added up to nothing less than 'a massive publicity drive on membership'. ${ }^{20}$ Andy Mullen notes that between July and October 1971 alone, ministers made 280 speeches on the subject, 'flooded the press with letters', and set up a European Unit within the Information Research Department (IRD) to rebut the claims of the anti-European camp.

In a more cohesive broadcast market than exists today, and when broadcasters were seen to be the agenda setters rather than the press, the government was able to concentrate its efforts to convince broadcasters on top rated news and current affairs on the BBC and ITV: 'Radio and television were particularly targeted, including programmes such as News at Ten, Panorama, Today, 24 Hours, Women's Hour and World at One'. ${ }^{21}$ In the interest of maintaining a veneer of balance, equal numbers of television and radio slots were set aside for broadcasts on behalf of the Britain in Europe (Yes) and the National Referendum

\footnotetext{
${ }^{18}$ Anthony King, Britain Says Yes: The 1975 Referendum on the Common Market (Washington, D.C.: American Enterprise Institute for Public Policy Research, 1977), pp.94-97; George Wilkes and Dominic Wring, 'The British Press and European Integration' in David Baker and David Seawright (eds) Britain For and Against Europe?: British Politics and the Question of European Integration (Oxford: Clarendon Press, 1998), pp.185205 (p.193).

${ }^{19}$ Baimbridge, ‘The Pre-history', p.59; Wilkes and Wring, ‘The British Press', pp.194-197.

${ }^{20}$ Paul Gliddon, 'The British Foreign Office', p164.

${ }^{21}$ Andy Mullen, 'From Imperial Third Force to the 1975 Referendum', in Baimbridge, ed., The 1975 Referendum, pp.60-76 (pp.73-74).
} 
Campaign (No) organizations in the last fortnight of the campaign. ${ }^{22}$ By referendum day, BBC 'Impartiality' polling found just 3\% of the audience thought there was 'a general BBC bias in favour of staying in. No one, it seemed, thought that the BBC was in favour of British withdrawal'. ${ }^{23}$ As one prominent Conservative Eurosceptic has reflected, being given airtime to make the case against the EEC was difficult enough: 'What was worse was how [the media] distorted whatever we said on the few occasions they gave any space to our views or the facts we stated'. ${ }^{24}$ The 1975 referendum debate is thus good territory on which to consider the positive messages about the EEC sent out by broadly the majority of parliamentarians and media agents.

Contemporary media coverage of the merits or otherwise of the EU in Britain exhibits a rather different set of tendencies. Now it is the pro-Europeans who feel marginalized or ignored: 'over the past twenty years, pro-Europeanism in this country has declined from being the intellectual mainstream of political discourse ... to a distinctly minority position, and not infrequently a persecuted one at that. ${ }^{25}$ In this interpretation the British are fed 'Fleet Street's blaring headlines about EU scandals and (specious) incursions such as its outlawing of square gin bottles and curved bananas' ${ }^{26}$ Cross-party pressure groups such as Britain in Europe have felt compelled to spend time and money rebutting the 'myths' that have grown up around the EU's regulation and red tape, sovereignty and bureaucracy. ${ }^{27}$ Meanwhile, websites such as Fullfact.org investigate misinformation about EU rules and regulations in the British press as part of its inquiries into the truth or otherwise of statistical claims made

\footnotetext{
${ }^{22}$ Anthony Smith, 'Broadcasting', in Butler and Kitzinger, The 1975 Referendum, pp.190-213 (pp.195-200).

${ }^{23}$ Philip Goodhart, Full-Hearted Consent: The Story of the Referendum Campaign - and the Campaign for a Referendum (London: Davis-Poynter, 1976), p.157.

${ }^{24}$ Richard Body, 'The 1975 Referendum', in Baimbridge, ed., The 1975 Referendum, pp.153-157(p.154);

Kieran O'Hara, The Referendum Roundabout (Exeter: Imprint Academic, 2006), pp.72-83 (p.88).

${ }^{25}$ Hugh Dykes and Brendan Donnelly, On the Edge: Britain and Europe (London: Forumpress, 2012), p.19.

${ }^{26}$ Schmidt, 'Adapting to Europe', p.26.

${ }^{27}$ Britain in Europe, Straight Bananas? 175 Anti-European Myths Exploded (London: Britain in Europe). See also Dykes and Donnelly, On the Edge, pp. 146-148.
} 
by politicians and journalists on a range of national public policy issues. ${ }^{28}$ The EU also engages in image management and myth-exposure through its Press Watch publication, ${ }^{29}$ however, the EU institutions themselves have been criticized for lacking professionalism in their dealings with journalists, especially those on the 'Brussels beat'. Even when UK Brussels-based journalists do cover EU affairs sympathetically the tone of the original copy can easily be altered since 'there is the capacity to give coverage a direct, Eurosceptic inflection where London editors think this is necessary'. ${ }^{30}$ In this view the EU is constructed, largely negatively in the UK, out of the messy process of news management by the institutions, the reporter's reading of the best story, and the editors' and proprietors' perceptions of the line on EU politics and the British position they believe their readers most want to consume. The economic downturn since 2008 has exacerbated the problem from a UK perspective. A 2012 report for the Centre for European Reform found that in 2005 there were six British daily newspapers with permanent correspondents in Brussels; seven years later there were just three, and one of those is based partly in Paris. ${ }^{31}$ Piecing all this together it can be argued that the EU's 'communication deficit' is part self-inflicted, part imposed upon it by the domestic focus of national media and increasingly a casualty of cutbacks in the age of austerity: 'lack of active communication, but also a lack of being communicated in the media'.32

\footnotetext{
${ }^{28}$ See for instance its March 2012 investigation into the Daily Express front page headline: 'Now EU Bans Plastic Bags', at http://fullfact.org/blog/Express_plastic_bag_ban_EU-6851. Claims made by EU supporters are given equal billing on its website, for example Nick Clegg's November 2011 assertion that 3 million British jobs depend on its EU membership, see http://fullfact.org/factchecks/Nick_Clegg_3_million_UK_jobs_rely_directly_on_EU-3087. Both accessed 27 March 2012.

${ }^{29}$ Neil T. Gavin, 'British Journalists in the Spotlight', Journalism, 2: 3 (2001), pp.299-314 (p.307); Anderson and Weymouth, Insulting the Public?, pp.154-155.

${ }^{30}$ Gavin, 'British Journalists', p.301 and p.304.

${ }^{31}$ David Rennie, The Continent or the Open Sea: Does Britain have a European Future? (London: Centre for European Reform, 2012), p.32. I am grateful to John Peet for drawing this report to my attention.

${ }^{32}$ Jochen Peter, Holli A. Semetko and Claes H. De Vreese, 'EU Politics on Television News', European Union Politics, 4: 3 (2003), pp.305-327 ( p.320).
} 
The sense of besiegement felt by pro-Europeans today is evident and comes from the fact that the permissive media consensus in support of the EEC in the 1970s almost entirely dissipated over the subsequent decades, to be replaced by a sullen discontent with the EU which, especially but not exclusively in its tabloid form, is 'highly conversationalised, emotive and often strongly xenophobic' ${ }^{33}$ In her biography of Boris Johnson, Sonia Purnell remarks that things altered in the reporting of Europe around the later 1980s and early 1990s to such a degree that by 1994 'there were only a few brave souls [amongst UK Brusselsbased journalists] left who still felt it safe to present themselves as unquestioning proEuropeans, at least in public.' In fact, Purnell credits Johnson with being the agent of change, helping make Euroscepticism 'an attractive and emotionally resonant cause for the Right., ${ }^{34}$ Significant though Johnson's stint as the Telegraph's Brussels correspondent might have been, the tone of his reporting echoed longer term developments within the newspaper industry that stimulated increasingly hostile coverage of 'Brussels' diplomacy. Part commercial decision, part ideational, it has all added up to a collapse in press support for the EU in Britain. To the 'vigorously anti-European agenda' of the Murdoch empire (including The Times, Sunday Times, Sun and now the Sun on Sunday ${ }^{35}$ ) and the Telegraph Group (Daily Telegraph and Sunday Telegraph) we can add the Harmsworth Group (Mail, Mail on Sunday and the influential agenda-setter in London, the Evening Standard) as well as the Daily Express and Sunday Express. ${ }^{36}$ Meanwhile, multi-million selling quarterly publications such as This England do their bit to present the case against Europe on the back of eulogies to

\footnotetext{
${ }^{33}$ Anderson and Weymouth, Insulting the Public?, p.61

${ }^{34}$ Sonia Purnell, Just Boris: The Irresistable Rise of a Political Celebrity (London: Aurum Press, 2011), p.115.

${ }^{35}$ The Sun on Sunday replaced the News of the World which Murdoch closed down in July 2011 on the back of the phone hacking scandal.

${ }^{36}$ Wistrich, 'Lessons', p.112; Brian Burkitt, 'The 1975 Referendum: Its Impact and Consequences', in Baimbridge, ed., The 1975 Referendum, pp.176-182 (p.180).
} 
the British countryside, its history and heritage - 'For all who love our green and pleasant land' as its website puts it. ${ }^{37}$

As newspapers that were formerly supportive of UK membership of the EEC have rethought their opinions since accession, and in particular during major periods of constitutional debate such as over Maastricht and Lisbon, so newspapers such as the Express which, as we have seen, were always critical of the European project, have shifted with them to retain a distinctive voice within this highly competitive marketplace. This 'chase' to the Eurosceptical end of a notional 'federalist-Eurosceptical' spectrum of opinion culminated in the Express launching a 'Get Britain out of Europe' campaign in November 2010, part of its 'struggle to repatriate British sovereignty from a political project that has comprehensively failed' and to help the British 'win back their country'. The newspaper advocates withdrawal from both the EU and from the 'alien, pan-European tribunal' that is the European Court of Human Rights from which 'It is time to break free'. ${ }^{38}$ As Peter Anderson observes, in presenting the EU as fundamentally dysfunctional with membership doing Britain more harm than good over the long-term, UK withdrawal has been on the covert agenda of newspapers such as the Express and Telegraph for some time. ${ }^{39}$ The Eurozone crisis has injected a greater sense of urgency to the reporting and unleashed what have probably all along been the Express's 'true' feelings about the EU, as well as letting it be seen to lead the way in opposing the EU to attract readers who might find the hopes that Britain can reform the EU from the inside fundamentally flawed or rather passé given the depth of malaise in the European project.

\footnotetext{
${ }^{37}$ This England website, http://www.thisengland.co.uk/single.htm?ipg=10677, accessed 31 August 2012; see also Daddow, New Labour and the European Union, pp.126-127.

${ }^{38}$ Express.co.uk, 'Get Britain out of Europe', http://www.express.co.uk/posts/view/213573/Get-Britain-out-ofEurope, accessed 17 March 2012.

${ }^{39}$ Peter Anderson, 'A Flag of Convenience? Discourse and Motivations of the London-based Eurosceptical Press', in R. Harmsen and M. Spiering, eds, Euroscepticism: Party Politics, National Identity and European Integration (Amsterdam: Rodopi), pp.151-70 (p.164).
} 
Providing something of an antidote to the Eurosceptical comment and analysis on the press side are the Guardian, Independent and Financial Times, although the Eurozone crisis has clearly shaken the latter's relative faith in the long-term viability of European sovereignty-sharing. ${ }^{40}$ Informed weeklies such as the Economist add a measure of balance to the overall picture, ${ }^{41}$ but in terms of readership numbers and therefore influence over the terms of the debate they cannot compete with the top-selling daily newspapers. Away from the press, the nature and impact of editorialization in the broadcast media are harder to assess with clarity because there is less empirical research to draw upon when reaching a verdict. On one hand, Dykes and Donnelly suggest that apart from the Murdoch-owned Sky channels 'The BBC and ITV are on the whole neutral on European issues, although both suffer from being over-reactive to the daily agenda of the overwhelmingly anti-European press. They certainly do not provide a counterpoint. ${ }^{, 42}$ Studies isolating broadcast data from newspaper reportage make less happy reading for those supportive of the European project. For example, Neil Gavin's content analysis of television coverage of the build-up and aftermath of the launch of the euro in 1998-2000 revealed a largely negative tone to the coverage with the British presented as 'embattled, besieged and threatened'; all in all Gavin judged the broadcasts to have been 'quite damaging to the image of the single currency'. ${ }^{43}$ On the other hand, the $\mathrm{BBC}$ is frequently accused of pro-European bias by critics clearly approaching the topic from a Eurosceptical perspective. Emblematic of this position is self-styled thorn-inthe-side of the chattering classes, Vernon Coleman, who cites BBC coverage of European affairs as his reason for labelling it 'A Biased Broadcasting Corporation'. ${ }^{44}$

${ }^{40}$ Dykes and Donnelly, On the Edge, p.142.

${ }^{41}$ Oliver J. Daddow, Britain and Europe since 1945: Historiographical Perspectives on Integration (Manchester: Manchester University Press, 2004), pp.90-92.

${ }^{42}$ Dykes and Donnelly, On the Edge, p.70.

${ }^{43}$ Neil T. Gavin, 'Media Coverage of the Single Currency in Britain: An Assessment of Television News in the First Year of the Euro', European Community Studies Association Conference, May-June 2001, http://aei.pitt.edu/2085/1/002102_1.pdf, accessed 18 April 2012,p.5 and p.8.

44 Vernon Coleman, 'The BBC - a Biased Broadcasting Corporation', (2007), http://www.vernoncoleman.com/biasedbr.htm, accessed 20 March 2012. 
Coleman accompanies his internet broadsides with self-publications including a book listing 250 reasons to reject the EU, a paean to 'freedom and liberty' dedicated to the memory of William Shakespeare, Winston Churchill 'and the other great Englishmen and Englishwomen who must now be spinning in their graves as the country they loved, respected, fought for (and in so many cases died for) is torn apart and threatened with extinction'. ${ }^{45}$ The $\mathrm{BBC}$ has taken to its editorial blogs to challenge these now long-running criticisms of its reporting on Europe by emphasizing how difficult it is, on a controversial topic such as Europe, 'for an impartial news organisation to report without inflaming strong views on either side of the debate' ${ }^{46}$ There is often more heat than light in the anti-BBC tirades and unvarnished critics aside, therefore, it is safer to agree with Gavin's reading of the mainstream UK coverage: 'few analysts of television coverage have criticized the BBC or ITV for editorializing' and, controversial issues such as the euro aside, the UK is not out of step with broadcasters from other nations when treated on a comparative basis. ${ }^{47}$

This article privileges press over broadcast coverage for two reasons. First, press reporting in the UK reflects continent-wide trends in paying more frequent attention to European affairs than does broadcast journalism, ${ }^{48}$ which tends to concentrate on the visually more appealing set-piece summitry and/or Europe-wide crises such as the Eurozone bailout negotiations. The second reason is that newspapers have increasingly performed the media agenda-setting function on European affairs in the UK, and where we are able most easily to track the shift from permissive consensus on Europe to destructive dissent. Put simply, the proportion of UK readers consuming Eurosceptic-inclined coverage of EU affairs now vastly

\footnotetext{
${ }^{45}$ Vernon Coleman, England Our England: A Nation in Jeopardy. Sound Reasons to Reject the EU (Barnstaple: Blue Books, 2004), dedication.

46 Helen Boaden, 'The challenge of reporting Britain's role in Europe', http://www.bbc.co.uk/blogs/theeditors/2011/12/the_challenge_of_reporting.html, accessed 20 March 2012.

${ }^{47}$ Gavin, 'British Journalists', p.305; see also Peter et al, 'EU Politics', p.321.[nb I am assuming the quotation comes from the Gavin, hence suggestion of 'see also' for Peter, just to clarify. Yes, both sources checked; Gavin is the quote.

${ }^{48}$ Leen d'Haenens, 'Euro-vision: The Portrayal of Europe in the Quality Press', Gazette: The International Journal for Communication Studies, 67: 5, 2005, pp.419-440 (p.422).
} 
outweighs those taking in 'neutral' or encouraging messages about the daily activities of the EU. The next section considers one of the most compelling reasons why: the Murdoch effect.

\section{The Murdoch effect}

'Mr Murdoch said...he wished me to change our European policies. If we couldn't change our European policies, his papers could not and would not support the Conservative government' ${ }^{49}$

A persuasive argument can be made that Rupert Murdoch's business interests override his interest in ideas or politics. Amelia Arsenault and Manuel Castells, for instance, have observed that 'Murdoch's political affiliations move swiftly in accordance, not with political ideology, but with News Corp's bottom line'. ${ }^{50}$ Lance Price suggests that 'Murdoch is a businessman first, second and last. Playing politics for politics' sake comes very down his list of priorities'. ${ }^{51}$ That Murdoch is known to back different parties in the same country at different elections might augment the impression that the mogul has no consistent ideology or set of ideals except one: making money for News Corporation. A supporter of Margaret Thatcher in the 1980s, the Murdoch press came out in support of Tony Blair in the run up to the 1997 election. By 2009 Murdoch had become disillusioned with New Labour - and the leadership of Gordon Brown in particular - such that he switched back to supporting David Cameron's Conservatives. The same has occurred in countries such as the US, where the

49 John Major, evidence to the Leveson Inquiry into media ethics, 12 June 2012, http://www.levesoninquiry.org.uk/wp-content/uploads/2012/06/Transcript-of-Morning-Hearing-12-June2012.txt, accessed 25 June 2012

${ }^{50}$ Amelia Arsenault and Manuel Castells, 'Switching Power: Rupert Murdoch and the Global Business of Media Politics: A Sociological Analysis', International Sociology 23: 4, 2008, pp.488-513 (p.497).

${ }^{51}$ Lance Price, 'Rupert Murdoch made PMs dance like puppets', http://www.dailymail.co.uk/debate/article2013082/News-World-phone-hacking-Ruper-Murdoch-PMs-dance-like-puppets.html, MailOnline 16 July 2011, accessed 16 April 2012 
Democrats and Republicans have gained at different times from Murdoch's financial and rhetorical backing in newspapers and on News Corp-owned television stations such as Fox News, launched in 1985.

There is no doubt that Murdoch likes to back a party (or a leader) which (or whom) he considers will be most amenable to his business interests. For example, when Murdoch came out in favour of Thatcher through the Sun in 1979 he was, 'Convinced that she held the key to the country's - and [the Tory press's] - future prosperity, they put their faith in her economic policies and trade union legislation. ${ }^{52}$ Two years later the government did not refer Murdoch's proposed takeover of The Times and The Sunday Times to the Monopolies and Mergers Commission, a clear signal for Price that the Conservatives effectively ignored the 1973 Fair Tract and 'intervened to protect Murdoch's interests.' ${ }^{53}$ The 1984 Trade Union Act made strike ballots mandatory and outlawed secondary picketing. 'With this law in place Murdoch was assured that he could combat inevitable attempts to thwart his newspaper's distribution [by print unions]. His friendly relationship with prime minister Margaret Thatcher had paid off' ${ }^{54}$ It set the scene for what would unfold at Wapping when Murdoch successfully locked the unions out of the new production plant, at a stroke reconfiguring the power relationships at the heart of the British newspaper industry and enabling 'Murdoch's media empire to become the largest in the UK' ${ }^{55}$

A decade after Wapping, Tony Blair backed a communications bill 'relaxing television and newspaper cross-ownership restriction, popularly called the "Murdoch Clause" because it applied only to News Corp. ${ }^{56}$ The bill allowed News Corp to purchase a controlling stake in ITV, one of the main ways in which the organization has 'clearly benefited from Labour's

\footnotetext{
${ }^{52}$ Greenslade, Press Gang, p.364.

${ }^{53}$ Lance Price, Where Power Lies: Prime Ministers v the Media (London: Simon and Schuster, 2010), p.252.

${ }^{54}$ Greenslade, Press Gang, p.470. The Wapping dispute is detailed at ibid., pp.469-478.

${ }^{55}$ Dominic Wring, "It's Just Business": The Political Economy of a Scandal', Media, Culture and Society, (forthcoming 2012), pp.1-6 (p.2).

${ }^{56}$ Arsenault and Castells, 'Switching Power', p.505.
} 
favourable positions on media regulation' ${ }^{57}$ It is on the issue of deregulation that we might also explain Murdoch's consistent opposition to the European project, 'which he opposes on the grounds that it imposes undue regulations on British business and provides no competitive advantage to the British media industry'. ${ }^{58}$ Murdoch willingly backed leaders such as Blair but he did so, it is alleged, on the implicit understanding that he would reconsider his position should they take Britain deeper into the EU integration process, particularly by joining the single European currency.

A former Downing Street insider has ventured that European affairs were part of a Faustian Pact between New Labour and the Murdoch machine, sealed when Blair and Brown flew to Australia to address News Corp executives shortly before taking office. Beginning work in Alastair Campbell's Downing Street Press Office in 1998, Lance Price was informed, 'We've promised News International we won't make any changes to our Europe policy without informing them. ${ }^{59}$ The beauty of such deals, Price continues, is that they could be unwritten but no less clearly communicated or binding for that. Apparently former Australian prime minister Paul Keating reassured Blair: 'You can do deals with [Murdoch] without ever saying a deal had been done. ${ }^{60}$ Steve Hewlett concurs: 'If you did a deal with Murdoch, you never needed to write it down - if he said it, he always stuck by it. ${ }^{61}$ When Blair refused to call a referendum on the proposed EU Constitutional Treaty in 2004 he was attacked vehemently by Murdoch, who personally insisted on the News of the World labelling the prime minister a 'traitor' in its headline attacking the decision. ${ }^{62}$ New Labour was also told that it would not receive the backing of News International titles in the 2005 general election

${ }^{57}$ Ibid., p.500

${ }^{58}$ Ibid., p.494.

${ }^{59}$ Price, Where Power Lies, p.347.

${ }^{60}$ Keating quoted in Price, 'Rupert Murdoch'.

${ }^{61}$ Steve Hewlett, 'Happy Birthday, Mr Murdoch!', British Journalism Review, 22: 1, pp. 5-7 (p.6).

${ }^{62}$ Anthony Seldon et al, Blair Unbound (London: Simon and Schuster, 2007), p.266. 
unless Blair did a U-turn. 'He did, and within days The Sun secured the scoop'. ${ }^{63}$ Backed by evidence on Murdoch's deal-making style and abhorrence of the European project the Faustian Pact reading of European policy-making under Blair has taken a real hold in policy and academic circles. ${ }^{64}$

On this first reading of the Murdoch effect, media regulation is at the forefront and politicians are in the box-seat, with Murdoch rather as supplicant, striving to channel the tides of political opinion in ways that suit his business interests through murky deals in the corridors of power. Yet we can turn that interpretation on its head and depict Murdoch as the principal ideas man, with the politicians coming around to his way of thinking on the political economy in modern Britain. This alternative and less widely acknowledged reading of the Murdoch effect sees politicians benefitting from the ideas and attitudes Murdoch has shaped through his media outlets and is well summarized by the Economist's Bagehot: 'Perhaps Mr Murdoch's biggest influence has been not so much in persuading people how to vote as in moulding a cultural and moral climate for politicians of varying hue to exploit.' ${ }^{65}$ To illustrate this interpretation we can turn to the work of David McKnight who prompts us to take seriously the role Murdoch's ideas have played in shaping political debates in Britain since the 1980s. A detailed study of The Sunday Times editorials and comment pages over the period of Andrew Neil's editorship (1983-1994), argues McKnight, reveals how politicians have come to accept the Murdoch worldview whilst dressing their acceptance up as a choice made in response to the demands of globalization and economic liberalization. The medium might change from broadsheet to tabloid, but the Murdoch message has been the same: deregulated free markets are under threat from the existence of a powerful EU.

\footnotetext{
${ }^{63}$ Price, 'Rupert Murdoch'.

${ }^{64}$ See for instance William Wallace, 'The Collapse of British Foreign Policy', International Affairs, 82: 1, pp56-68 (p.63). The contours of the debate are surveyed in Daddow New Labour, p.175-177.

${ }^{65}$ Bagehot (Economist), cited David McKnight, 'The Sunday Times and Andrew Neil: The Cultivation of Market Populism', Journalism Studies, 10: 6 (2009), pp.754-768 (p.755).
} 
McKnight argues that Murdoch led the way in establishing a transatlantic 'bridge' or platform for ideas to be exchanged between Britain and the US during the Ronald ReaganMargaret Thatcher years. The flow of traffic across the bridge was largely one way, with The Sunday Times under Neil importing into the UK a 'local variant' of Reagan's 'conservative populism' in the form of 'market populism'. This approach 'championed a view of economic markets which saw them as the friend of the ordinary people and which damned critics of markets as "establishments" and "elites". There is insufficient space in this article to drill down into the detail of this macroeconomic position, for example on the tenets of Keynesian economics, the perils of high social spending and the welfare state, or indeed how Neil constructed the 'establishment' - including the reviled, anti-competition BBC - opposed by the Murdoch press. Two points are, though, of relevance. First, the Neil agenda went some way beyond what Thatcher was enacting in Britain. Second, this 'radical' outlook came from a long-standing engagement with centre-right think tanks in the US; 'No think tank from the left or centre has any kind of relationship to either Murdoch [or] his news media. ${ }^{66}$

How did Neil express Murdoch's thinking in his coverage of the EEC? Under his editorship The Sunday Times articulated an informed Eurocritical position which tested some of the linguistic furniture which would then feature in tabloid coverage, as we will see in the following section. McKnight gives the example of one of The Sunday Times's early campaigns which were 'often framed in terms of the ordinary people' and covered consumer protection issues rather than industrial relations or the structural needs of the British economy, including topical themes such as airline cartels and limited weekend shopping hours. ${ }^{67}$ From there it was not a large step to take on the iniquities of the EEC's Common Agricultural Policy (CAP) which was explicitly framed in terms of an attack on 'fat payments

${ }^{66}$ David McKnight, 'Rupert Murdoch's News Corporation: A Media Institution with a Mission', Historical Journal of Film, Radio and Television, 30: 3 (2010), pp.303-316 (p.307). On the same trend at The Times see Price, Where Power Lies, p.253.

${ }^{67}$ McKnight, 'The Sunday Times', p.759. 
from Brussels' to the farmers. ${ }^{68}$ In 1985 - three years before Thatcher's Bruges speech - one Neil editorial railed that 'It is bad enough that so much is squandered on uneconomic French peasants. But it is absurd that it should be squandered to pay the highest food prices in the EEC to part-time Bavarian farmers who drive to their weekend farms in their Mercedes. ${ }^{69}$ Opposing touchstone EEC policies using the 'straight-talking' language of the 'common man' (and it was 'man') became the characteristic Murdoch position which has survived to the present. When pushed in 1999 on whether the expansion of his television interests through News Corp Europe might help him consider closer British ties with Europe, Murdoch's answer was a blunt 'No'. On the single currency his position was clear from the outset: 'As far as we are concerned, we think the Euro's a great mistake. ${ }^{70}$

Three things stand out from Andrew Neil's editorship stint at The Sunday Times. First, his coverage framed 'soft' Eurosceptic concerns (in this case a quite rational critique of the inflexibility and inefficiencies in Europe's farming policy) using bombastic Eurosceptic language reminiscent of Murdoch's own blunt manner. ${ }^{71}$ Neil's critique of the economic failings of 'the traditional European mixed economy' from the vantage point of his newspaper's 'radical' alternative, particularly on the need for low government spending and low levels of taxation, was mixed with direct populist-style attacks on individual EEC nations in a manner more associated with the tabloid press (see below). Second, Neil's attention to EEC failings pre-dated by some distance the mainstreaming of Eurosceptical opinions that occurred through the 1980s. When the contentious issue of the transition from EEC to EU did become a hot topic for political discussion in the UK, The Sunday Times and its Murdoch tabloid stable mates had been crafting a workable socially conservative populist line to take on European matters for several years. Both their loci for attack but more importantly the

\footnotetext{
${ }^{68}$ Brian MacArthur cited in McKnight, 'The Sunday Times', p.760.

${ }^{69}$ Quoted McKnight, 'The Sunday Times', p.759.

${ }^{70}$ Murdoch quoted in Hagerty, "'I don't do it for the money", p. 10

${ }^{71}$ McKnight, 'Rupert Murdoch's News Corporation'.
} 
language they used were picked up on by politicians trying to find a narrative about the British in Europe and the wider world that resonated in the post-Falklands War era. Third, the Murdoch empire has not been the only repository of hard and/or xenophobic Euroscepticism in Britain. Although in newspaper terms Murdoch has been the pace-setter on Europe he has been joined by some very willing accomplices in the form of latter-day press barons in the mould of Lords Beaverbrook and Rothermere who have sought, sometimes but not always in vain, to impose their preferred vision for Britain on the political class. ${ }^{72}$ Richard Desmond at the Express and Conrad Black and later the Barclay brothers at the Telegraph and Sunday Telegraph have mimicked the Murdoch position to their readers.

Murdoch has, however, performed a vital agenda-setting function through both the rhetorical devices used to 'report' Europe and the level of personal interest he has taken in cultivating his empire's approach to European issues, particularly in his favourite UK outlet, the Sun. The following section will delve deeper into the political-media nexus that has legitimated and promoted the transmission of hard Euroscepticism in Britain since the 1980s.

\title{
From the broadsheets to the tabloids: Euro-criticism becomes Euroscepticism
}

\author{
'[Blair] also feared a backlash from the Murdoch papers, especially the Sun. A \\ referendum was now a step too far. ${ }^{73}$
}

Tabloid coverage of European affairs took on a qualitatively different tone in Britain during the 1980s. It became more bombastic, injected a greater sense of urgency into the debates by presenting treaty reforms as major threats to British sovereignty and identity, became less

\footnotetext{
72 For example Beaverbrook's unsuccessful Empire Crusade which had media and political wings in the late 1920s and 1930s. See Lance Price, Where Power Lies: Prime Ministers $v$ the Media (London: Simon and Schuster, 2010), p.75.

${ }^{73}$ Peter Mandelson, The Third Man (London: HarperPress), p.254.
} 
deferential to politicians and 'elites', and was deeply critical of 'foreign' machinations that threatened supposedly objective British interests. We can explain this with reference to the Murdoch effect and in particular the manner in which trusted editors such as Kelvin Mackenzie at the Sun reframed the national interest around a 'macho' martial interpretation of Britain's history and role in the world. The 'chauvinism' about Europe and Europeans that in 1989 Norman Gelb judged to be 'unfashionable' outside the 'far Right fringe' had in fact come to be the language of hard Euroscepticism in Britain, tipping the balance from a legitimate 'proud sense of insularity' symbolized by Thatcherite discourse on British nationhood into rank stereotyping and strident jingoism. ${ }^{74}$ Already at the time of the 1984 budget rebate crisis the Sun had jumped on a campaign by French farmers to reduce imports of British lamb with the headline 'Hop Off You Frogs', accompanied by badges, a spoof 'raid on Calais and the publication of anti-French jokes. ${ }^{75}$ The 'beef war' of 1996 would be reported in the same fashion. ${ }^{76} \mathrm{~A}$ litany of headlines such as the Sun's 'Cattle of Britain' of 22 May that year sustained a threat narrative that constructed Britain fighting another battle against an external enemy (the 'Brussels' beef ban) which threatened to undermine what a Daily Express leader in March 1996 called Britain's existence as ‘an independent sovereign nation with control over our own affairs' ${ }^{77}$

Underpinning what were becoming routine attacks on Britain's leading partners in the EEC/EU there was a discernible drift into the use of military language and metaphor to frame newspaper coverage of international affairs, the Falklands War acting as an important catalyst in this regard. Roy Greenslade, then at the Sun, recalls that in the build-up to the British campaign in the South Atlantic the newspaper set about taking on the role of chief

\footnotetext{
${ }^{74}$ Norman Gelb, 'Thatcher at Odds with Europe', The New Leader, 72: 16 (October 30, 1989), p.12.

${ }^{75}$ Greenslade, Press Gang, p.422.

${ }^{76}$ See Wilkes and Wring, 'The British Press', pp.200-204. The 'beef war' denotes the diplomatic and media hostilities that broke out when the EU imposed a ban on British beef exports after the discovery of Bovine Spongiform Encephalopathy (BSE) or 'mad cow disease' in March 1996. The ban was lifted in June 1996.

${ }^{77}$ Rod Brookes, 'Newspapers and National Identity: the BSE/CJD Crisis and the British Press', Media, Culture and Society, 21: 1 (1999), pp.247-263 (at p.247 and p.260).
} 
cheerleader for military action against the perceived 'appeasement' of the Foreign Office and Foreign Secretary Lord Carrington. 'I soon realised that Bouverie Street was now the unofficial war office with Kelvin Mackenzie playing chief of staff and Petrie [Tom - News Editor] in the role of his aide-de-camp' ${ }^{78}$ The Mirror and other Sun competitors were lumped in with the Foreign Office and asked why they believed during every international dispute 'Britain is wrong and the foreigners right?' In jumping to Thatcher's side so vociferously the Sun was both giving reign both to its ideological predilections and carving out a distinctive position at odds with the generally more cautious approach of other press at the time, stooping to 'levels of bad taste that had never been seen before' ${ }^{79}$ Several imperatives were at work. Certainly 'Mackenzie saw the opportunity not just to support the war against Galtieri but to open a second front by fighting the war that mattered most to him and to Murdoch, sales. ${ }^{80}$ This made sense because, as Martin Dunn observes, the Sun in the 1980s was battling to become the pre-eminent tabloid newspaper in Britain and was 'involved in one of the great newspaper wars of all time with the Daily Mirror' ${ }^{81}$

The blurred boundaries between patriotism and jingoism in the early 1980s help us appreciate how the framing of news stories can impact on the popular imagination, with research suggesting that 'When British press reporters caricature Europe and Europeans they marry the language of the stereotype to an underlying racist discourse of cultural difference, isolation and economic threat. ${ }^{82}$ It is noteworthy in this regard that foreigner-bashing had been a part and parcel of media coverage of international affairs in key segments of the UK media for several years before Thatcher's Bruges speech, which is often heralded as a turning point in alerting the British public to the perils of 'ever closer union' with Europe. Instead of being the catalyst her supporters might suggest, it did not take much in and around the

\footnotetext{
${ }^{78}$ Greenslade, Press Gang, p.442.

${ }^{79}$ Price, Where Power Lies, p. 259

${ }^{80}$ Greenslade, Press Gang, p.442.

${ }^{81}$ Martin Dunn, 'How to Survive Rupert Murdoch', British Journalism Review, $18: 4$ (2007), pp.5-10 (p.8).

82 Gavin, 'British Journalists', p.306.
} 
coverage of the Bruges speech to alert Thatcherites within and outside government to the idea that the European Community could be fitted into the threat narrative. ${ }^{83}$

If anything it was the Maastricht ratification process that gave the Murdoch-Thatcher consensus on Europe the sustained period it needed to flourish and take a hold of the British national psyche. It opened a two-year window during which European affairs became infused with the high drama of British politics as Prime Minister Major fought openly with Eurosceptic backbenchers to push the Maastricht legislation and the European Communities (Finance) Bill through a volatile parliament. Gifford is correct to argue, therefore, that 'The parliamentary debate over Maastricht reflected the continued political currency of the arguments made by Thatcher in her Bruges speech' ${ }^{84}$ Thatcherites inside and outside the press effectively rehashed arguments against Europe and Europeans either as revenge for her removal from office by pro-Europeans in November 1990 and/or out of principled opposition to monetary integration after the pound sterling was forced unceremoniously from the system of fixed exchange rates on Black Wednesday in September 1992. ${ }^{85}$

The 'intensification of anti-European activity in Britain' 86 around the time of the Maastricht Treaty goes some way to showing the synergies between the Thatcher foreign policy agenda and Murdoch-inspired Euroscepticism. Equally noteworthy but less fully researched, however, was the high priority accorded within Britain's European policy narratives at this time to xenophobic and especially Germanophobic sentiments which drew on recent military encounters to draw attention to the alleged unfinished nature of Germany's historic expansionist ambitions. ${ }^{97}$ This was where the straight-talking opinion of

\footnotetext{
${ }^{83}$ For a deconstruction of the Bruges speech and its aftermath see Oliver Daddow, 'Margaret Thatcher, Tony Blair and the Europe Question in British Foreign Policy', British Journal of Politics and International Relations special issue (forthcoming in 2013).

${ }^{84}$ Gifford, 'The Rise of Anti-imperial Populism', p.863.

${ }^{85}$ Peter Hennessy, The Prime Minister: The Office and its Holders since 1945 (London: Penguin, 2000), pp.460467.

${ }^{86}$ Matthew Sowemimo, 'Evaluating the Success of the Labour Government's European Policy', Journal of European Integration, 21: 4, pp.343-368 (p.347).

${ }^{87}$ Anderson and Weymouth, Insulting the Public?, p.68
} 
the 'man in the street' met the populist prime minister seeking to reach out to the middle England masses. For instance, it is alleged that at a secret Chequers seminar in 1990 Margaret Thatcher claimed that the reunified Germany was trying to achieve through European integration what it could not attain through wars because it was in their 'unreliable character' to act this way. ${ }^{88}$ Not long afterwards the Secretary of State for Industry made these thoughts public, suggesting in The Spectator in July 1990 that the Community was 'a German racket'. He went on to impute to European integration the unfolding of a German plot: 'I'm not against giving up some sovereignty in principle, but not to this lot. You might as well give it up to Adolf Hitler. ${ }^{89}$ Nicholas Ridley was sacked for this comment, but with politicians giving such cues to newspaper owners and editors occasionally in public but most likely off the record, it is no surprise that hard Euroscepticism has come to be associated with some of the most visceral and unappealing elements of the British national psyche. In April that year the Sun, which generally left Germanophobia to The Times, Telegraph, Mail and Express, ${ }^{90}$ had fused mockery of Labour leader Neil Kinnock with anti-Germanism and Euroscepticism by commenting that while Thatcher was a 'champion' for combating the threat of a European superstate, Kinnock would be 'shaking the clenched fist of Euro-power ... warbling "Deutschland über Alles". ${ }^{91}$

Now, the British political elites were not alone in being wary of a reunified Germany after the end of the Cold War. President François Mitterrand of France and the Netherlands' Prime Minister, Ruud Lubbers, both 'expressed their fears more or less forcefully' at the time. ${ }^{92}$ However, that Thatcher and the Thatcherites should display such 'deep distrust of

\footnotetext{
${ }^{88}$ Urban quoted in Spiering, 'British Euroscepticism', pp.141-142.

${ }^{89}$ Ridley quoted in ibid., p.141.

${ }^{90}$ Anderson and Weymouth, Insulting the Public?, p.87.

${ }^{91}$ Cited Greenslade, Press Gang, p.609.

92 Julie Smith, 'How 1989 Changed the History of European Integration', European View, 8 (November 2009), pp.255-262 (p.257).
} 
German motives', ${ }^{93}$ and in such a manner, opened political but perhaps more importantly discursive space within which the history of Anglo-German enmity could be revisited in the context of ever more fraught debates over the future shape of the EU. For public consumption, of course, anti-German sentiment was subsumed into arguments about how best to 'contain Germany by a balance of power', ${ }^{94}$ but the legitimating effects of this antiGerman sentiment in and around the time of the Maastricht ratification process cannot be underestimated. It reached an unpleasant nadir in tabloid coverage of the football match between England and Germany during the Euro96 tournament, when the Mirror joined the Sun and other tabloids in dredging up a series of unsavoury war metaphors on the day of the contest, imagery that was repeated across the tabloids and broadsheets in the rematch at the same competition in $2000 .{ }^{95}$ As Greenslade has observed, xenophobia of this kind has rarely been far from tabloid coverage of European affairs - political and cultural - over recent decades, making not inaccurate John Major's description of Murdoch's Sun: 'the house magazine of England-against the world' ${ }^{96}$

\section{Conclusion}

This article has argued that it may well be appropriate to argue that 'no one knew what was coming' when Rupert Murdoch begin to build his UK media empire in the 1960s. We now have a clearer if not definitive picture, with the Murdoch effect having been seen in several dramatic ways throughout the period of Britain's EEC/EU membership. The rise of the Murdoch empire and especially the style of reporting is an essential - perhaps the essential -

\footnotetext{
${ }^{93}$ Dinan, 'The European Community', p.20.

${ }^{94}$ William Cash quoted in Gifford, 'The Rise of Post-imperial Populism', p.863.

${ }^{95}$ Hywel Bishop and Adam Jaworski, "'We Beat "em": Nationalism and the Hegemony of Homogeneity in the British Press Reportage of Germany versus England during Euro 2000', Discourse and Society, 14: 3 (2003), pp.243-271.

${ }_{96}$ Greenslade, Press Gang, p.657; Major quoted at p.620.
} 
explanation for the broader media drift from permissive consensus to destructive dissent on the question of British-Europe relations. Two conclusions flow from the preceding analysis.

First, Murdoch's deep ideological and commercial interest in influencing European policy at the national level has transformed a long established and not intrinsically unhealthy British suspicion of 'things Continental' into an alarmist call to arms against 'Europe' through tabloid sensationalization and scare stories about the 'Brussels' effect on everyday life in Britain. British foreign policy-makers have long had a troubled relationship with their European counterparts because, at root, they have been unclear about Britain's identity and interests, and how best to protect and promote those interests in a rapidly changing international arena through the twentieth century. The loss of the overseas Empire combined with growing calls in Scotland and Wales for the dissolution of the 'empire' closer to home disrupted Britain's calm sense of self that had survived intact even the upheavals of the Second World War.

The turn to Europe in the 1960s and 1970s was a symptom of Britain's identity angst but it would soon become a casualty of it. Where it has been reported seriously at all, 'Europe' has routinely been depicted in the opinion-forming sections of the British print media as a necessary evil in the post-imperial world and as a poor second, at best, to the 'special relationship' with the US. As influential segments of the media became increasingly hostile and laced with nationalist bigotry, so politicians came to believe that the scope for serious and sustained public discussion of European affairs was dangerous to their personal careers and party political fortunes. From accusations of verbal 'deals' to direct threats to change policy, the Murdoch effect on European policy in the UK might not have been decisive in determining politicians' approaches to European integration, but was surely instrumental in engendering a climate of fear on European issues that must have featured in pro-European politicians' calculations about what was and was not possible in this vital realm 
of British foreign policy. Certainly the evidence from the Blair years is that fear of Murdoch inhibited any proactive moves on controversial European topics such as a referendum on joining the single currency or, later, the Lisbon Treaty. Further research might usefully branch out more than I have been able to here to study the sociological, ideological and commercial factors in the broader press drift from permissive consensus to destructive dissent through the 1980s and 1990s.

The second conclusion is that within a fifteen year period of joining, pro-Europeanism had gone from being the mainstream position within British politics to a sideshow. ProEuropeans were caught off guard and, as their sensitivity to the veiled threats emanating from the Murdoch empire grew, they became less and less willing to counter systematically the Eurosceptic challenge, either organizationally or in terms of providing a coherent alternative narrative to the Eurosceptic rendering of Britain's global position. Depending on one's point of view, pro-European politicians have either demonstrated a lack of leadership on European questions in Britain since accession, or they have played a cunning political game, calculating that on a relatively low salience issue such as Europe they can appease Murdoch at no great cost (and some likely benefit) to their electoral fortunes at general elections. In sum, the Murdoch effect on media coverage of the EU in Britain has been dramatic. It has altered the terms of the debate from 1973 to 2012 by convincing politicians from across the political spectrum that they should fear the EU and more importantly the backlash of the press should they try to publicize a more constructive position on European integration. Tabloid outrage against 'Europe' has become the stock national style of debating European affairs in Britain and this is unlikely to change in the near or even the distant future bar some radical changes in media ownership or ideology. 